\title{
TRENDS OF ETHNIC CONFLICTS IN CROSS RIVER STATE, NIGERIA
}

\author{
BISONG, THERESA LARRY, Ph.D \\ DEPARTMENT OF AGRICULTURAL EDUCATION, \\ CROSS RIVER STATE COLLEGE OF EDUCATION, AKAMKPA, \\ CROSS RIVER STATE, \\ NIGERIA. \\ EREMI, EMMANUEL OHARA, PH.D \\ DEPARTMENT OF AGRICULTURAL EXTENSION \& RURAL SOCIOLOGY \\ UNIVERSITY OF CALABAR, CALABAR, \\ NIGERIA. \\ DOI: $10.31364 / \mathrm{SCIRJ} / \mathrm{v} 6.111 .2018 . \mathrm{P} 1118586$ \\ http://dx.doi.org/10.31364/SCIRJ/v6.i11.2018.P1118586
}

\begin{abstract}
The main objective of this study was to assess the trends of ethnic or communal conflicts in Cross River State for a period of fifteen years 2001 - 2016. The study was conducted in Cross River State, Nigeria. Cross River State comprises of eighteen (18) Local Government Areas and Nine (9) Local Government Areas were purposively selected for the study because they are the conflict areas of the state. These selected local government areas include; Abi, Biase, Boki, Etung, Obubra, Obudu, Yala, Odukpani and Yakurr respectively. The effective sample size used for the study was four hundred and forty seven (447). Data were collected with the aid of observation, focus group discussion, interviews and a questionnaire. Data obtained were analyzed using frequency tables and trend analysis. The study therefore recommended that the government and nongovernmental organizations should organize enlightenment programs to sensitize the people on the need for peaceful coexistence and consequences of conflicts, developmental programmes on skill acquisition or entrepreneurship should be conducted in the warring communities, especially those communities that conflict has been reoccurring, to enable the youths acquire skills that will create employment, security personnel should be deployed to warring communities and finally the root causes of conflict in the communities should be investigated by the appropriate authorities and solution sort to bring lasting peace in the area.
\end{abstract}

Keywords: Trends and Ethnic Conflicts

\section{INTRODUCTION}

Ethnic conflict is one of the major threats to international peace and security (Reuter, 2012). Ethnic conflict is the form of conflict in which the objectives of at least one party are defined in ethnic terms, and the conflict, its antecedents and possible solutions are perceived along ethnic lines. The conflict is usually not about ethnic differences themselves but over political, economic, social cultural or territorial matters. The end of the cold war saw a transition towards peace in many areas in which conflict had been fuelled by East-West antagonism (Slobodanka, 2003) but as the antagonism declined, new wars broke out and in the period $1990-2001$, there were over 57 different major armed conflicts in 45 locations around the world (Stockholm International Peace Research Institute, 2002). Most of these locations were in developing countries and more than half of the least developed countries including African countries have experienced major armed conflicts during the past 20 years (Eihzgerald, 2000). 
The case of Mozambique and that of Rwanda also induced weakness on the economy of these countries. Most of the new conflicts between 1998 and 2001 took place in Africa and Asia (SIPRI, 2002). Statistics showed output losses for all developing countries from 1970-1997 to amount to about \$121 billion at 1995 prices, or an average of $\$ 4.3$ billion per year (Food and Agricultural Organization, 2006). Also, between 1980 and 1990, conflict induced losses in developing countries exceeded the value of total food aid of all types to those countries (FAO, 2009).

Nigeria has witnessed series of ethnic violent conflicts which have led to blood bath and wanton destruction of properties. Some of these conflicts include the Oduduwa People Congress (OPC) and Hausa traders. In Lagos in 1999, conflict between local farmers and Fulani cattle rearers in Shaki, Oyo state in 2000, Warri communal clash in Delta State in 1999, ethnic-religious crisis in Kano, Bauchi and Maiduguri in 2006, Kala ethnic crisis in 2009, ethnic violence in Nasarawa State in 2001 and the Boko Haram and Niger Delta insurgences which have become almost unabated in recent years just to mention but a few (Popoola and Alao 2012).

Ethnic or communal conflicts have become a consistent experience across different local government areas of Cross River State. Traditionally, Cross River State has witnessed communal conflicts of diverse proportions and fatalities in recent years, these conflicts have grown in occurrence and assumed more dangerous and sophisticated dimensions. For example, the Ebom Versus Ebijiakara conflict of 2005 and 2006 left one of the communities (Ebijiakara) without a place called home, the Adadama and Ikwo conflict has left many dead and properties worth millions of naira destroyed, the Wanikade and Wanihem conflict in Yala Local Government Area was a humanitarian disaster. The Boje and Nsadop conflict in Boki Local Government Area is tittering on the brink of humanitarian emergency while the Onyadama versus Nko and Oderegha versus Inyima conflict in Obubra and Yakurr Local Government Areas have been perenniated. The list of ethnic or communal conflicts in Cross River State is endless, painfully, these conflicts have left most, if not all the affected communities underdeveloped and impoverished.

Consequently, conflicts in Cross River State have become intermittent, often very destructive and occurring more frequently. it is against this background that this study became necessary to assess the trends of ethnic conflicts in Cross River State, Nigeria.

\section{SIGNIFICANCE OF THE STUDY}

The study assessed the trends of ethnic conflicts and it will be of immense benefit to a number of people, both in the private and public sectors. Information in this study will draw the attention of the government, non-governmental organizations, private individuals and peace makers to communities that are prone to conflicts and to areas were conflict has been reoccurring. Information on the time series and periodic variation matrix of the occurrence of conflicts in the study area will enable the government and 
nongovernmental organizations to understand the months and seasons that conflict is likely to occur and adopt new approaches to reduce or avoid the occurrence of conflict in the area.

Non-governmental organizations will benefit from the information obtained in the course of this research as it will serve as a source of information on decision making in their programme, planning and implementation in the rural communities.

\section{METHODOLOGY}

The study was carried out in Cross River State, Nigeria. Cross River State is made of eighteen (18) Local Government Areas. However the study focused specifically on nine (9) selected Local Government Areas that have historically and in recent times been associated with communal or ethnic conflicts. The local government areas selected include; Abi, Biase, Etung, Odukpani, Obubra, Obudu, Yakurr and Yala respectively.

Purposive sampling technique was used to select Cross River State and the various Local Government Areas Studied. Also, the selection of some communities in the various local government areas was purposively done based on the fact that these communities have recorded conflicts. The selected communities were segmented into focus - groups of fifteen (15) members each for discussion. Five (5) key informants from each local government area were also selected for a detailed interview and the effective sample size used for the study was four hundred and forty seven (447) respondents. Data obtained were analyzed with the aid of frequency counts and trend analysis.

TABLE 1: Trends of Ethnic Conflicts in Cross River State (2001 - 2016)

\begin{tabular}{ll}
\hline Year & Conflict \\
\hline April, 2001 & Isobo and Ofonekpani of Obubra and Ikwo L.G.As of Cross River and Ebonyi \\
& States. \\
Feb., 2002 & Appiapum and Ofatura in Obubra L.G.A of Cross River State \\
March, 2002 & Ikot Ana and Ufot Ugbem in Biase L.G.A of Cross River State \\
June 2003 & Etankpini and Oban Okoroba in Akamkpa L.G.A of Cross River State.
\end{tabular}

March, $2004 \quad$ Ikot Udia and Obio Usiere in Odukpani L.G.A of Cross River State. 
April, 2004

2005.

Oct. 2006

2007

January, 2007

February, 2007

2008

March 2009

Jan. 2010

Feb. 2010

April, 2010

Oct. 2010

August, 2011

April,2012

June, 2012

Sept., 2012

April 2012
Boje and Esobendeghe in Boki L.G.A of Cross River State

Ikot Ana and Ufot Ugben in Biase Local Government Area of Cross River State.

Uwet and Akpab-Okoyong in Odukpani LGA, CRS.

Ogbeche, Afrike \& Njua - Bano in Ogoja and Boki Local Government Areas, CRS.

Nko and Onyadama in Yakurr and Obubra Local Government Areas, CRS

Kutia and Ukwortong in Obudu LGA of CRS.

Usumutong and Ijom - Abanyong of Abi and Biase L.G.A's of Cross River State

Ediba and Usumutong in Abi L.G.A, CRS

Boje and Nsadop in Boki L.G.A of Cross River State.

Ochon and Alesi in Obubra and Ikom L.G.A's, CRS.

Nko and Onyadama in Yakurr \& Obubra LGAs of CRS

Ofenekpa and Isobo in Ikwo and Obubra L.G.A's of Cross River \& Ebonyi States.

Abebene and Ovokwa in Obubra L.G.A, CRS.

Ajassor and Efraya in Etung L.G.A., CRS 


Nov. $2016 \quad$ Utia and Ukwortong in Obudu LGA, CRS

Source: Field survey (2017)

Note: $\quad$ L.G.A = Local Government Area

CRS $=$ Cross River State

TABLE 2: Time series and periodic variation matrix of ethnic conflicts in cross River State, 2001-2016

\begin{tabular}{|c|c|c|c|c|c|c|c|c|c|c|c|c|c|}
\hline Year/Month & Jan & Feb & Mar & Apr & May & Jun & Jul & Aug & Sept & Oct & Nov & Dec & RT \\
\hline 2001 & & & & 1 & & & & & & & & & 1 \\
\hline 2002 & & 1 & 1 & & & & & & & & & & 2 \\
\hline 2003 & & & & & & 1 & & & & & & & 1 \\
\hline 2004 & & & 1 & 1 & & & & & & & & & 2 \\
\hline 2005 & & & & & & & & & & & & & 0 \\
\hline 2006 & & & & & & & & & & 1 & & & 1 \\
\hline 2007 & 1 & 1 & & & & & & & & & & & 2 \\
\hline 2008 & & & & & & & & & & & & & 0 \\
\hline 2009 & & & 1 & & & & & & & & & & 1 \\
\hline 2010 & 1 & 1 & & 1 & & & & & & 1 & & & 4 \\
\hline 2011 & & & & & & & & 1 & & & & & 1 \\
\hline 2012 & & & & 2 & & 1 & & & 1 & & 1 & & 5 \\
\hline 2013 & 2 & & & 1 & 1 & & & & & & & & 4 \\
\hline 2014 & & 1 & & 1 & & & & & & & 1 & 1 & 4 \\
\hline 2015 & & & & 1 & & 1 & & & 1 & & & & 3 \\
\hline 2016 & 1 & 1 & & 2 & & & & & & 1 & 3 & 1 & 9 \\
\hline $\mathrm{CT}$ & 5 & 5 & 3 & 10 & 1 & 3 & 0 & 1 & 2 & 3 & 5 & 2 & 40 \\
\hline
\end{tabular}

Source: Field survey, 2017

Note: $\mathrm{CT}=$ Column total, $\mathrm{RT}=$ Row total

Tables 1 and 2 indicates the time series and periodic variation of ethnic conflicts in the study area from 2001 to 2016. The time series showed monthly occurrence of conflicts each of the years. The time series revealed that between 2001 and 2016 studied, there was no 
record of conflict in 2005 and 2008. Conflicts occurred once in the following years; 2001, 2003, 2006, 2009, and 2011. There were records of conflict twice in 2002, 2004, and 2007. The year 2015 recorded conflict in the study area thrice while 2010, 2013 and 2014 recorded conflicts four times respectively. Year 2012 recorded conflicts five times while year 2016 recorded conflict nine times. The year 2016 was seen to have recorded the highest incidence of conflicts within the time studied. The time series analysis of the trends of ethnic conflicts in the study area, from 2001 to 2016 is represented graphically in Figure 1.

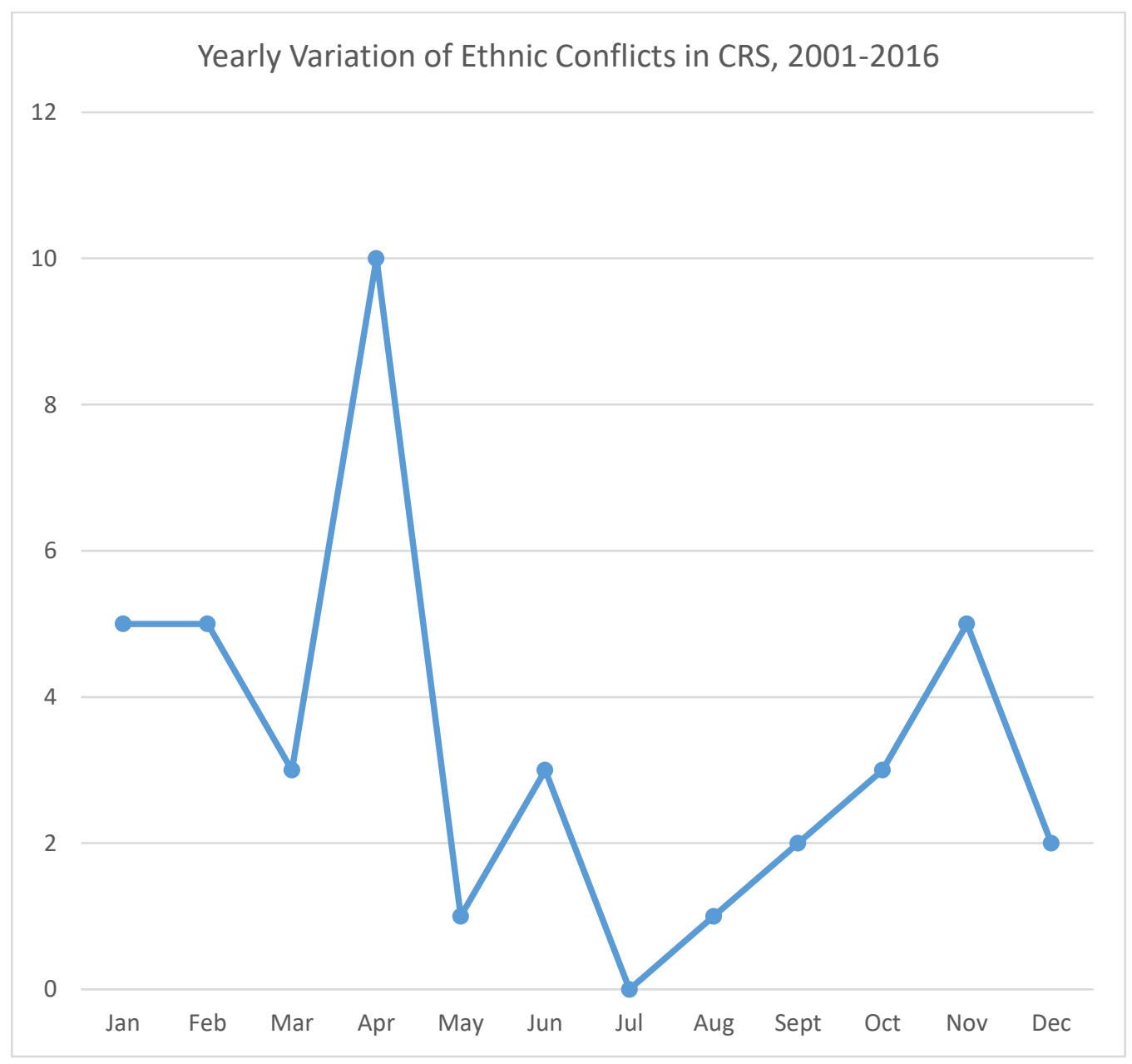

FIG. 5: Trends of ethnic conflicts in Cross River State, 2001 -2016

www.scirj.org 


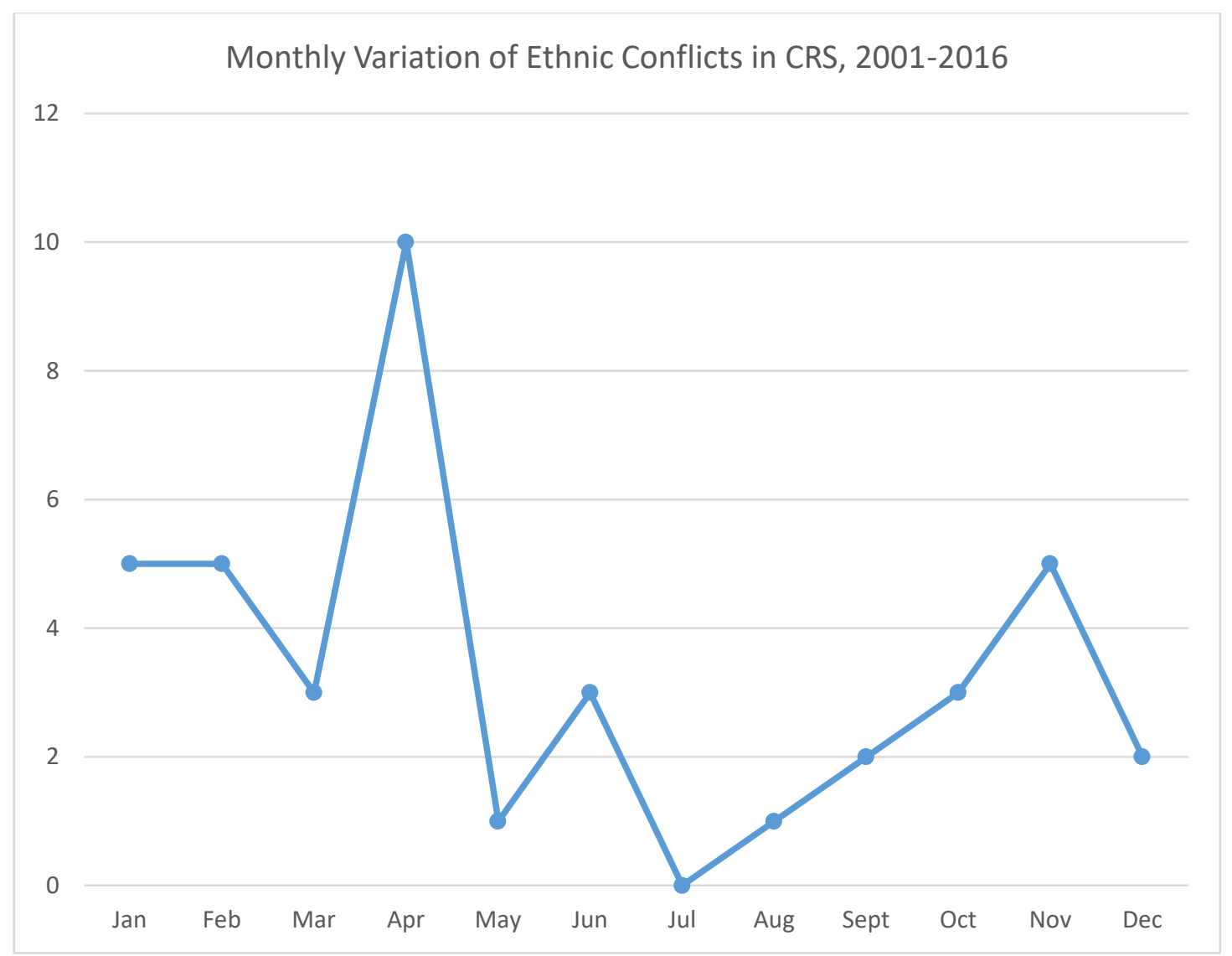

FIG. 2: Periodic variation of ethnic conflict in Cross River State, 2001-2016

www.scirj.org

(C) 2018, Scientific Research Journal

http://dx.doi.org/10.31364/SCIRJ/v6.i10.2018.P1118586 
The periodic variation of ethnic conflicts in Cross River State (figure 1 and 2) indicates that only the month of July recorded absolute zero conflict for the 15 years period. The months of May and August recorded one occurrence of conflict respectively for the 15 years period. September and December recorded conflict twice for the period, while March, June and October recorded conflict thrice for the period studied. The months of January, February and November recorded five incidence of conflict. However, the month of April has 10 occurrence of ethnic conflicts for the 15 years period studied. From the findings, the month of April recorded the highest incidence of conflict, followed by November, January and February.

The high occurrence of ethnic conflicts in recent years may be as a result of continued struggle for scarce resources. This increased struggle may also be as a result of hard economic realities in the State and nation at large, which can be linked to the economic recession. This brings about low income and low sustainability of the people who now mostly involve themselves in farming activities that result in the struggle for land. The assertion here may be backed up by the fact that the periodic variation in ethnic conflicts recorded high frequency of occurrence in April, which is the month that farming activities are always at their peak. In line with the findings, Cross River State department of conflict resolution (2017) reported that conflicts among neighboring communities have been reoccurring over the years mostly during the planting season and recently it is on the increase.

\section{Conclusion and Recommendations}

Ethnic or communal conflicts have become consistent experience across different local government areas in Cross River State, Nigeria. Some communities have witnessed conflicts of diverse proportions and fatalities.

In recent years, these conflicts have grown in occurrences and assumed more dangerous and sophisticated dimensions as conflicts have become intermittent, often very destructive and occurring more frequently. Hence, the need for the government, nongovernmental organizations and all stakeholders to find lasting solutions that will lead to peaceful coexistence and development in the area.

The study therefore recommended that the government and non-governmental organizations should organize enlightenment programmes to sensitize the people on the need for peaceful coexistence and consequences of conflicts, developmental programmes on skill acquisition should be conducted in the warring communities to avail the youths of skills that will enable them be gainfully employed. Also, security personnel should be deployed to warring communities within the months of high occurrence of conflicts and finally, the root causes of conflicts in the communities should be investigated by the appropriate authorities and solution

Sorted to address the issues concerned and bring lasting peace in the area. 


\section{REFERENCES}

FAO, (2006). Food Security, Policy Brief, June, 2006. Issue 2, Food and Agriculture Organization, Rome.

Fitzgerald, E. V. (2000) Global Linkages, Vulnerable Economics and Outbreak of Conflict; Nafitzer

Popoola, M and Alao, D. (2012). The Effects of Religions Violence on Political Instability in Nigeria, Babcock Journal of Social Sciences, Vol. 19 No. $1 \& 2$

Reutger, T. K. (2012) Ethic Conflict, Encyclopedia Britannica, Inc.

Stockholm International Peace Research Institute (SIPRI) (2002), (http://www.sipri.org)

Cross River State Department of Conflict Resolution; (2017) Reports on Communal Conflicts; Governors Office, Calabar, Nigeria. 